\title{
The political ecology of hazard vulnerability: marginalization, facilitation and the production of differential risk to urban wildfires in Arizona's White Mountains
}

\author{
Timothy W. Collins ${ }^{1}$ \\ University of Texas at El Paso, USA
}

\section{Introduction: political ecology, marginalization, and facilitation}

By fostering the integration of a wide range of tools and theoretical approaches in the critical study of human-environment relations, political ecology has ascended to a prominent position in anthropological and geographical scholarship since Eric Wolf (1972) first coined the term. The field developed largely through studies of peasant production in the Third World (i.e., Less Developed Countries, the South- see M. Watts 1983; P. Blaikie 1985; P. Blaikie and H. Brookfield 1987; T. Bassett 1988; N. Peluso 1992). There has been growing effort to expand the scope of the field by transporting its approaches to other humanenvironment situations, including those in the First World (e.g., P. Robbins et. al 2001; T. Sheridan 2001; J. McCarthy and J. Guthman 1998; J. McCarthy 2002; R. Schroeder 2005; M. Brogden and J. Greenberg 2003; R. Schroeder et al. 2006). This work has demonstrated that - with careful contextualization - political ecology can be used to understand First World human-environment relations.

While political ecology can orient inquiry in varied circumstances, scholars have questioned its uncritical use in First World situations. Bryant and Bailey (1997) chose to title their volume Third World Political Ecology due to the fundamental socio-environmental differences thought to exist between the global North and South. In particular, Paul Robbins articulated the need to more carefully consider the role of large state and market institutions in mediating First World human-environment relations (P. Robbins 2002; 2004). The concept of "marginalization" was elaborated through studies of how the least powerful social groups in Third World countries are made vulnerable to socio-environmental changes. Marginalization connotes how social inequalities limit the livelihood options of these groups, leading them to degrade landscapes and occupy hazardous environments, constraining their abilities to cope with environmental changes (P.Susman et al. 1983; P.Blaikie and H.Brookfield 1987; P.Robbins 2004). Based on early political ecology studies, it was postulated that the least powerful groups and classes in a given society inhabit the most hazardous environments (P. O'Keefe et al. 1976). Paul Susman and colleagues (1983:277-278) exemplify the early political ecological perspective on marginalization:

The 'marginals' are those who have either been forced off the land or onto very poor or insufficient land...They often live in the most dangerous and unhealthy places. It is no accident that a major slum in San Juan (Puerto Rico) is frequently inundated by high tide [or] that the poorest urban squatters in much of Asia live in hazardous floodplains...It is believed that the international division of labor among rich and poor countries, and market forces within the poor underdeveloped capitalist economies of the Third World, cause the poorest of the poor to live in the most dangerous places. The process of underdevelopment is intimately linked with the control and exploitation of indigenous resources by the governing elite and outside interests. The underdevelopment process forces the peasantry into a more vulnerable position, which, in turn, directs them to look for another source of livelihood in areas where security may be less and hazard more severe or to change their resource use in ways that exacerbate vulnerability.

While the concept of marginalization outlined above is parsimonious and applicable in particular settings, human-environment relations are more complex and multifaceted. Subsequent empirical

\footnotetext{
1 Assistant Professor of Geography; Department of Sociology and Anthropology, University of Texas at El Paso, 500 West University Avenue, El Paso, TX 79968; Phone: 915-747-6526; Fax: 915-747-5505; Email: twcollins "at" utep.edu. I thank Kevin McHugh, Bob Bolin, Pat Gober, Eric Keys, Stephen Pyne, Sara Grineski, and Cristina Morales for their very constructive comments and suggestions on drafts culminating in the completion of this article. Those who made the field component of this research possible must be recognized, including Sue Sisson, as well as members of the Natural Resources Working Group and the White Mountain Stewardship Project Multi-Party Community Monitoring Board. I am also grateful for the institutional support I received, without which this work would not have been feasible. The article stems from research funded by a Mathew G. Bailey Scholarship, a Graduate and Professional Student Association Dissertation Research Grant, a Millennium Interdisciplinary Dissertation Fellowship, and a National Science Foundation Integrative Graduate Education and Research Training in Urban Ecology Fellowship, all through Arizona State University; an Association of American Geographers Dissertation Research Grant; and the City of Show Low, Arizona. Any errors of content or omission are my own. This paper was awarded the Eric Wolf Prize, Political Ecology Society, 2007.
} 
examinations of global connections between poverty and the "hazardousness of places" have concluded that the relationships postulated by Third World political ecologists are not universal (e.g., R. Kates and V. Haarman 1992).

Nonetheless, the marginalization perspective has remained influential in subsequent statements made about the political ecology of risks, hazards and disasters. Rather than re-theorize marginalization, scholars have typically qualified the concept and implied that human behavior can explain environmental decision-making where there is a hazard risk in the First World (e.g., B. Wisner et al. 2004). ${ }^{2}$ Social science studies of natural hazards in the U.S. (including political ecology) have tended to reinforce these assumptions, using 'voluntary choice' models (M. Davis 1999; C. Rodrigue 1993). Cronon (1996:31-32) exemplifies the typical First World perspective:

...the people who build in exposed locations like these - the locations most susceptible to fire and mud - are often those with the greatest ability not to do so. Hillside real estate...commands prices in Los Angeles that only the wealthiest homeowners can afford. To spend millions of dollars to live suspended in midair above fire-prone vegetation...would seem to make no sense at all. And yet while standing in the ashes with scenes of devastation in all directions, one can easily see why people build here anyway. The views from these places are breathtaking. Why do they do it? They put themselves and their families at risk for the simple reason that they want to be close to nature.

Some have noted that, in contrast to marginalization processes driving the production of vulnerability in the Third World, prevailing First World social arrangements (e.g., insurance coverage, land use regulations, emergency response and disaster relief subsidies) enable residential development and the security of privileged groups in amenity-rich areas subject to destructive biophysical events (W. Fulton 1995; M. Davis 1999; C. Rodrigue 1993; P. Gardner and L. El-Abd 1984; D. Hemenway 1987). While these studies reinforce rather than destabilize the First/Third World dichotomy, they also provide important insights by directing attention to institutional arrangements that enable the First World's wealthiest to occupy hazardous landscapes on the metropolitan periphery. To incorporate these insights within political ecology theory, one must re-theorize the marginalization thesis.

In this paper, I extend the scope of the political ecology approach to focus on marginalization and its antithesis, facilitation. Social arrangements in developed countries appear to facilitate residential development and the security of privileged groups in highly valued areas that are subject to high magnitude biophysical hazards. This idea of "facilitation" denotes how powerful groups are provided security to exploit environmental opportunities associated with hazardous places for private gain, with deleterious social and ecological consequences.

The paper demonstrates the utility of conceptually linking marginalization and facilitation in order to develop more complete explanations for human-environment relations in particular places. I focus specifically on the case of wildfire hazards in Arizona's White Mountains, USA. First, I introduce the study area. I then discuss the political ecology approach to studies of hazards and disasters. After outlining the methodological approach, I examine the root causes of hazard vulnerability in the region, describing how local social groups and ecological communities have articulated with political economic change. This provides the context for explaining how processes of marginalization and facilitation have inscribed patterns of differential hazard vulnerability within two general types of residential landscapes in the region, which I refer to as livelihood and lifestyle landscapes. I conclude by discussing implications of the study for political ecological understandings of risks, hazards and disasters.

\section{The study area: Arizona's White Mountains, USA}

Large fires have occurred with increasing frequency in forests of the U.S. West (S. Pyne 2003; General Accounting Office 1998; T. Swetnam and C. Baisan 1996). In recent decades many fire-prone landscapes have urbanized. These trends have led to unprecedented wildfire disasters and have announced regional crises of 'forest health' ${ }^{3}$ and wildfire safety. The Rodeo-Chediski fire in 2002 destroyed large areas of Arizona's White Mountains. Over 90,000 residents were evacuated from settlements along an $80 \mathrm{~km}$ transect, as the fire encompassed nearly 200,000 ha and destroyed some 465 homes. The fire cost nearly $\$ 22$ million to fight, led to an estimated $\$ 329$ million in direct damages, and burned over 300 million board feet

\footnotetext{
2 For example, in the classic political ecology of hazards text At Risk, B. Wisner and colleagues (2004:13) state that "...living in the hazardous canyon environment is voluntary for the rich in California, but not for the poor Brazilian and Filipino job-seeker who lives in a hillside slum...This...is a situation in which neither 'voluntary choice' models nor the notion of 'bounded rationality' is applicable."

3 While land management concerns about 'forest health' are central to current forest policy debates, it is a contentious concept within biogeography/ecology; hence, my use of quotes.
} 


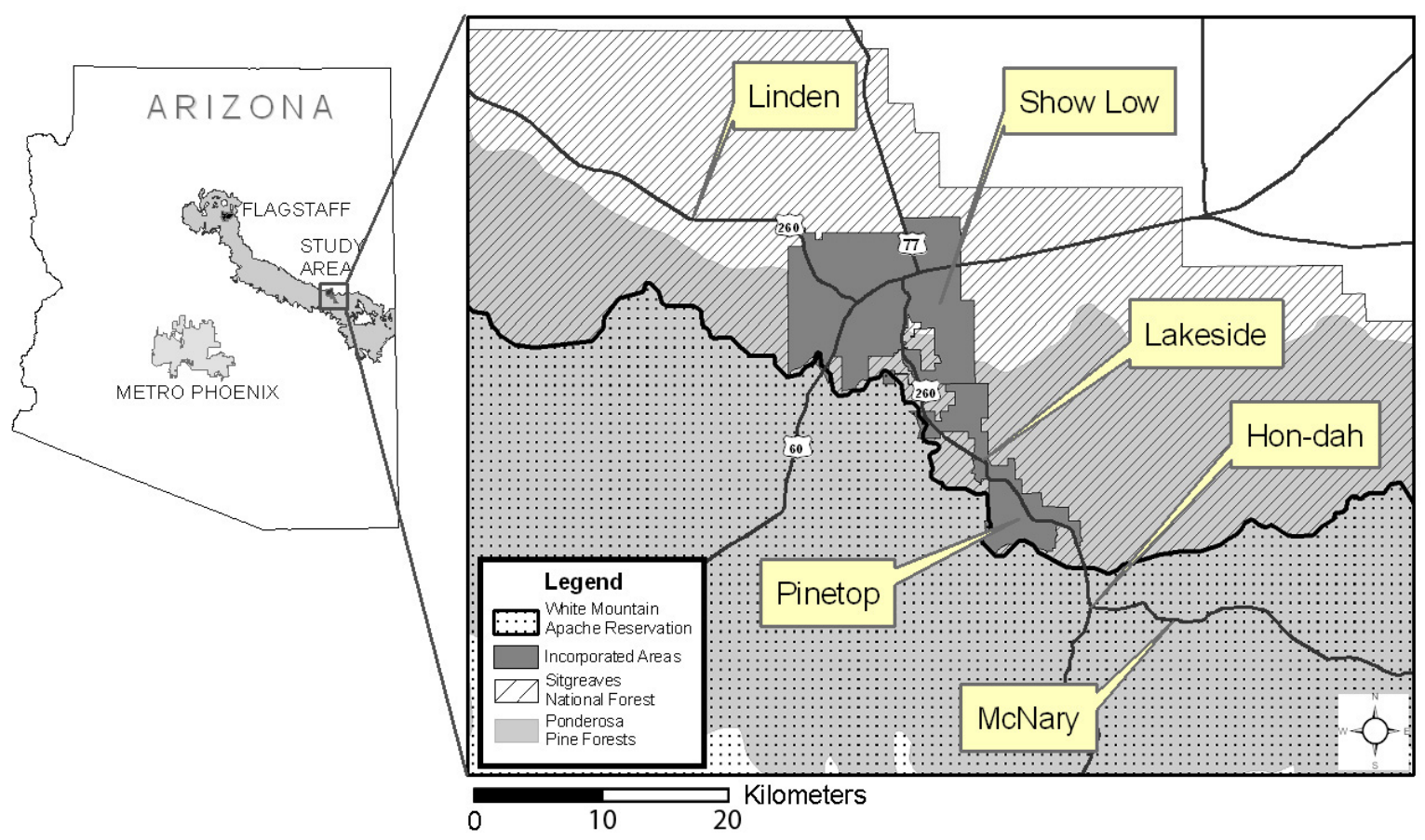

Fig. 1. The study area: Arizona's White Mountains, USA

of timber (R. Ring 2003). "More than 100,000 acres [40,000 ha] burned so hot that they looked like a smoldering parking lot" (R. Ring 2003:14). Fires of this magnitude are outside the historical range of variability for Southwestern ponderosa pine and indicate amplified fire hazard and ecological degradation (W. Covington 2003). The convergence of degraded forests with a prolonged drought led to a bark beetle epidemic that has resulted in high rates of tree mortality in Southwestern pine forests (D. Breshears et al. 2005). In central Arizona, one-third of ponderosa pine forests have qualitatively changed, as have the lives of people connected to them.

The Mogollon Rim stretches across Arizona from the city of Flagstaff to the White Mountains, marking the southern edge of the Colorado Plateau (Figure 1). It contains the largest ponderosa pine forest in the world. In the absence of human manipulation, climatic patterns promote the development of a pine-grass savanna maintained by frequent low intensity surface fires. Within these forests humans have modified ecological patterns and processes. The geography of the region can be understood as a palimpsest of successive political economic shifts with corresponding cultural in-migrations and land use changes ( $T$. Sheridan 1995). Before Anglo-American settlement, the region was home to the Apache. Mormons arrived in the late 1800s and established a self-sustaining network of permanent settlements. Beginning in the late 1800s and continuing through the 1980s, natural resource extraction oriented to external markets functioned as the region's economic engine. Changes in the orientation of capitalism post-World War II (WWII) accompanied a shift in values, and facilitated the emergence of an environmental amenity economy fueled by aesthetics, 'naturalness,' and other resources provided by the in situ mountain environment. Today, a diverse populace - composed of White Mountain Apache, descendants of Mormon settlers, and others with histories in resource extraction, as well as growing numbers of amenity migrants and Hispanic service providers - live in the White Mountains. The humanized environment includes a variety of residential settings situated in a tapestry of dense forests, woodlands, and grasslands. Most notably, the region exhibits acute fire hazard, as indicated by the massive Rodeo-Chediski fire of 2002.

I selected six neighboring and very different communities as case studies. At the outset I recognized that differing local experiences of vulnerability may be shaped by varying socio-historical differences in environmental resource priorities, by diverse institutions that structure resource access and control, and by ecological variability and the legacies and pathways through which landscapes respond to use. Located along a $30 \mathrm{~km}$ stretch of Arizona State Highway 260, Linden, Show Low, Lakeside, Pinetop, McNary, and Hondah differ appreciably in ecological, social, cultural, political, and economic terms (Table 1). Pinetop, Lakeside, Show Low, and Linden were founded by Mormon pioneers, while McNary and Hon-dah are within the White Mountain Apache Reservation (A. Gomez 2001). Pinetop, Lakeside, Linden, and Show Low are predominantly Anglo, although there are small and growing Latino populations (Table 1). Pinetop is prototypical of the 'new' economy of the U.S. West. Catering to the environmental values of affluent 


\begin{tabular}{|c|c|c|c|c|c|c|c|c|c|c|c|c|}
\hline \multirow[b]{2}{*}{ Community $^{1}$} & \multicolumn{5}{|c|}{ Demographics } & \multicolumn{2}{|c|}{ Socioeconomics } & \multicolumn{5}{|c|}{ Housing } \\
\hline & 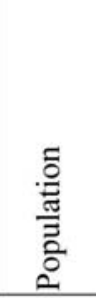 & 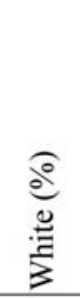 & 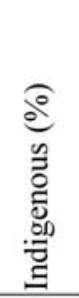 & 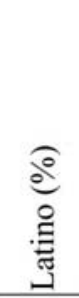 & 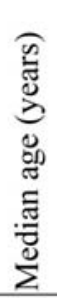 & 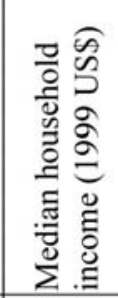 & 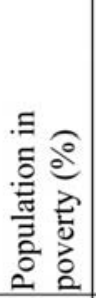 & 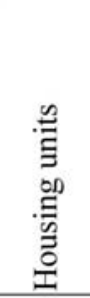 & 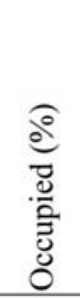 & 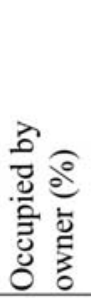 & 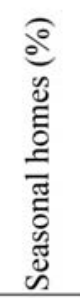 & 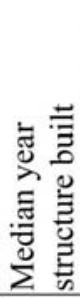 \\
\hline Linden & 1,227 & 93.6 & 0 & 4.8 & 35 & 36,719 & 24.0 & 706 & 34.0 & 83.7 & 34.4 & 1985 \\
\hline Show Low & 8,246 & 90.4 & 3.1 & 9.7 & 36 & 32,825 & 14.3 & 4,678 & 66.5 & 74.8 & 28.5 & 1983 \\
\hline Lakeside & 6,813 & 86.6 & 5.0 & 11.8 & 39 & 35,343 & 12.9 & 4,765 & 53.5 & 76.0 & 41.5 & 1981 \\
\hline Pinetop & 4,524 & 90.7 & 2.6 & 8.7 & 45 & 48,401 & 8.5 & 5,495 & 33.6 & 83.1 & 61.6 & 1981 \\
\hline McNary & 351 & 5.4 & 85.5 & 11.7 & 19 & 4,375 & 81.5 & 102 & 26.5 & 10.3 & 0 & 1982 \\
\hline Hon-dah & 395 & 1.5 & 89.1 & 15.9 & 26 & 45,430 & 18.2 & 200 & 30.1 & 23.3 & 17.5 & 1980 \\
\hline
\end{tabular}

Source: US Bureau of the Census 2000, summary tape files 1 and 3

' Communities are comprised by Navajo County, AZ census block groups (BGs). Linden includes tract 9607, BG 1; Show Low tract 9611, BGs 1-3 and tract 9612, BGs 1-3; Lakeside includes tract 9612, BG 4 and tract 9613, BGs 1-3; Pinetop includes tract 9613, BG 4 and tract 9614, BG 1-3; and Hon-dah includes tract 9401, BG 1. McNary includes Apache County tract 9401 , BG 1.

Table 1. Socio-demographics of the case study communities

urbanites, this densely forested community maintains a burgeoning amenity-dependent economic sector. While the permanent population is less than 4,000, on summer weekends and holidays, Pinetop's population approaches 30,000 (LSD 2004). ${ }^{4}$ Show Low is a larger town with a more diversified economy and a more varied ecology. While Show Low's forested residential environs cater to amenity migrants, the community is also a permanent home to groups that constitute the local workforce, many of whom reside among grasslands and woodlands. Nearby unincorporated Linden is composed primarily of permanent residents of larger, pastoral lots. It also contains a few more densely forested subdivisions that cater to amenity migrants. The adjacent White Mountain Apache Reservation lands are home to a generally younger and predominantly indigenous population. Some reside in the former Southwestern Forest Industries mill town of McNary, where over 80 percent of people live below the poverty line. Those more fortunate live in newer residential subdivisions developed near the Hon-dah Resort Casino. Field observations indicate socioeconomic variability within these communities that is undocumented by census data, with mobile homes being situated, for example, in relatively close proximity to exclusive dwellings.

\section{Hazard vulnerability and urban wildfires}

\section{Studies of hazard vulnerability}

One of political ecology's intellectual roots lies in studies of hazards and disasters. In the mid-1970s a group of geographers and anthropologists studying the role of global political economic structures as influences on Third World disasters initiated a critique of the biophysical and behavioral emphases - and the Western and First World biases - of conventional hazards research (e.g., B. Wisner et al. 1976; P. O'Keefe et al. 1976; E.Waddell 1977). ${ }^{5}$ Acknowledging that some people are more vulnerable in the context of a specific hazard than others, the "political ecologies of hazard" focused on how social inequalities influence the risks confronted in everyday life and how they affect capacities to cope with loss (M. Watts 1983; K. Hewitt 1997; A.Oliver-Smith and Hoffman 1999; B. Bolin with L. Stanford 1998; B. Wisner et al. 2004). By risk, political ecologists mean the compound function of biophysical hazard exposure and peoples' vulnerability, i.e., their ability to anticipate, respond to, and recover from a hazard event (B. Wisner et al. 2004). Following O'Riordan and Timmerman (2001:436), vulnerability "relates inevitably to power, the ability to exert control by right or threat. [It] can be interpreted as a loss of power in the creation of one's own

\footnotetext{
4 This is evident in the proportion of seasonal dwellings in the housing stock (Table 1).

5 This alternative perspective more fully coalesced with the 1983 publication of Interpretations of Calamity from the Viewpoint of Human Ecology (K. Hewitt 1983a).
} 
future." As a relational term, vulnerability refers to the combination of factors that influence the degree to which someone's life, livelihood, property, or assets are put at risk by the occurrence of a hazard event. ${ }^{\circ}$

Vulnerability is connected to three linked realms: root causes, dynamic pressures, and unsafe conditions (B. Wisner et al. 2004). The root or underlying causes refer to the wide historical, political, economic, demographic, and environmental factors that produce unequal distributions of resources among people. Dynamic pressures are processes and activities, including, for example, population change, rapid urbanization, environmental degradation, global economic pressures, and political conflict. These processes translate the effects of root causes by creating unsafe conditions under which some people in a given place and time must live. In analyzing vulnerability, particular forms of unsafe conditions have to be considered in relation to the specific hazards facing people (B. Wisner et al. 2004:54). While unsafe conditions may involve both the spatial location and the characteristics of the built environment, they also include fragile livelihoods, resource dependency, inadequate incomes, legal and political inequities, and a lack of preparedness for emergencies (B. Bolin with L. Stanford 1998). Root causes, dynamic pressures, and unsafe conditions are all subject to change through time. Social vulnerability and security are relational attributes that articulate with these processes, and also change through time.

To focus analyses, B. Wisner (1993:19-21) identified three core components of vulnerability: livelihood security, self protection, and social protection. The livelihood component refers to people's abilities to command resources through employment, subsistence activities, or related means that can be used or exchanged to satisfy needs. Those with higher and more stable income opportunities are said to have secure livelihoods, while those with lower and unstable income opportunities have insecure livelihoods. Livelihood security varies by social relations (e.g., gender, class, race, ethnicity, age) and systems of domination, which include state actions to promote or restrict livelihood opportunities.

Self protection and social protection pertain to issues of hazard preparedness and mitigation at household and broader societal levels. Self-protection is provided by, and for, the household and involves people's biophysical exposure, including where and in what they live (B. Bolin with L. Stanford 1998). Selfprotection directly relates to socioeconomic factors (income in particular) because households can to an extent 'buy' safety (e.g., by purchasing a hazard resistant dwelling or a home site in a less hazardous environment). Cultural traditions and preferences as well as technical knowledge about how and where to build, also play roles in self protection. Social protection refers to the presence (or absence) of hazard precautions or preparedness provided by the state, market, and local collective action. Social protection is a function of non-monetary social relations as well as state and non-governmental institutions operating at various levels. Mutual aid in a community, neighborhood, or among extended family, as well as technical knowledge of hazards, building codes, land use planning, emergency management, and disaster response assistance are all parts of social protection. Ken Hewitt (1997) asserted that a key element in social protection for vulnerability reduction is 'equitable protection', rather than the level of technological sophistication available in state and other agencies.

Contextualizing differential risk is foundational to political ecology approaches to risk analysis. Social and biophysical processes linked with past times and to different places, bear on contemporary experiences of hazard vulnerability in the White Mountains. Like many landscapes of the U.S. West, the White Mountains are in the midst of a shift from 'old' to 'new' sets of relations epitomized by an uneven transition in environmental values from those prioritizing resource extraction (e.g., ranching, logging, mining) to those oriented by nature consumption (e.g., tourism, recreation, second-home development). This process is leading to increasing social inequality and to cascading patterns of hazard vulnerability within communities. Such cross-scale interactions contribute to what Ben Wisner and colleagues have termed the "concatenation" of vulnerability (2004:16). This idea underscores how risk (i.e., hazard vulnerability) is an emergent property of complex, mutually constitutive processes that produce associations among multiple (sometimes seemingly disparate) social and environmental attributes in specific contexts. As such, the concept of concatenation offers an antidote to treating hazard vulnerability merely as a checklist of essential and mutually exclusive items.

\section{Research on urban wildfires}

Most scientific and management interventions into wildfire hazard vulnerability proceed from biophysical science (e.g., J. Cohen 2000). But social factors influencing residential fire hazards at the individual level have also received scholarly attention. Traditionally, scholars have adopted a behavioral perspective founded on the assumption of biophysical risk causation (T. Collins 2005a; S. McCaffrey 2004). ${ }^{7}$ While providing valuable insights into the roles of perceptions, values, and risk management institutions as

\footnotetext{
6 Such factors are context-dependent but often include gender, class, age, race, and ethnicity (B. Wisner et al. 2004).

7 Three hypothetical influences on residential decision making and wildfire risks have been examined in considerable depth: hazard perceptions, amenity value conflicts, and institutional incentives (for a detailed discussion see T. Collins 2005a; 2005b).
} 
factors that influence residential decision making, these studies have avoided scrutiny of the role of differential access to resources as emphasized by political ecologists (i.e., social vulnerability). ${ }^{8}$ Existing studies of social influences on 'wildland-urban interface' fire hazards either implicitly or explicitly assume that households are exercising free residential choice. ${ }^{9}$

The limited conception of residential decision-making and risk orienting previous studies has not been subject to political ecological critique. As discussed earlier, most political ecology studies of hazards in the U.S. have perpetuated a First/Third World dichotomy, reinforcing rather than destabilizing assumptions about the freedom of residential choice (B. Wisner et al. 2004; M. Davis 1999; C. Rodrigue 1993). While these studies have critically examined the socio-institutional structures that facilitate the security of the First World's wealthiest in the face of wildfire hazards, they perpetuate the assumptions that hazardous living pertains exclusively to the affluent, and that it results from free residential choice.

While forests of the U.S. West are often represented as 'wilderness' playgrounds for the affluent, history reveals that they are much more than this (B. Willems-Braun 1997). Wildfire hazard and rural poverty coexist in many locales throughout the U.S. West, where legacies of colonialism (P. Limerick 1988), underdevelopment (W. Robbins 1994; 1999) and resource dependency (J. Kusel 1996; S. Doak and J. Kusel 1996) have been determinants of hazard vulnerability. A third of the 13 million 'wildland-urban interface' residents of the U.S. West "lack incomes sufficient to meet basic economic needs, much less the cost of adequate wildfire protection" (K. Lynn 2003:10). While affluent amenity seekers have been facilitated in occupying specific incendiary landscapes, they are relative newcomers to the rural U.S. West, coexisting alongside indigenous peoples, descendants of early settlers, natural- resource-extractors, (increasingly Hispanic) service providers, and others. The experiences of these less powerful groups conceptually map to their marginalization, which has been overlooked. The reality of a socially diverse First World in its forests casts doubt on simplistic representations of at-risk residents and explanations of their relationships to environmental hazards.

In order to understand processes of marginalization and facilitation, I looked in detail at how local people and institutions have articulated with political economic change. I examine the historical decline of an extraction-oriented economy founded on natural resource production and the emergence of an amenity-based economy predicated on the consumption of nature. A critical distinction about who is at-risk in this political economic context must be made. Many households in the White Mountains choose to maintain secondary homes in hazardous locations and to eschew mitigation. Many do so because they wish to maximize environmental values, and only under the condition that property insurance is made available to externalize their probable losses. While such households are exposed to extreme levels of fire hazard, they are not vulnerable (nor are they at high risk) based on political ecology definitions. Property insurance provides a form of security that facilitates their search for beauty in the face of danger. In contrast, other White Mountain households live in highly hazardous sites, have few assets to invest in mitigation or fire insurance, and have highly insecure livelihoods due to the loss of employment in the extraction economy or their underemployment as service workers in the amenity economy. Many such households suffer from acute hazard exposure as well as social vulnerability. For some households, the narrowing of livelihood options has reduced their access to resources, which has constrained investment in hazard reduction, indicating a process

\footnotetext{
8 Rather than being a focus of inquiry, potential effects of variable access to resources have been systematically controlled for in studies. For example, M. McKee and colleagues note (2004:493) that "households will only undertake averting [i.e., mitigation] actions when the subjective expected utility of the action exceeds the expected utility of the resources used in the actions." In reality, resources vary by household. Unfortunately, in their experiments, participants were allotted the same resource portfolio, and the role of the initial residential selectivity was ignored (M. McKee et al. 2004). Also, in research involving actual residents as subjects, renters are typically screened as participants, while homeowners only are included in analyses (e.g., K. Nelson et al. 2003; C. Vogt 2003). There have been recent acknowledgements within the fire science community of the importance of social capacity in terms of gradients in human resources (L. Kruger et al. 2003; A. Cheng 2003). However, in these cases emphasis has been placed entirely on community level characteristics critical to fire hazard mitigation and disaster recovery (e.g., social capital). I have found only two references that discuss socioeconomic constraints of reducing wildfire risk at the household level (R. Hodgson 1995; Insurance Services Offices 1997). Hodgson's (1995) study of barriers to residential adoption of mitigation measures revealed that cost, time demands, potential conflicts with aesthetics, physical demands, and the difficulty of disposing large of amounts of vegetation generated from the initial conversion to defensible space were significant barriers. Insurance Services Offices (1997:20) identified "the cost of implementing mitigation plans" among the reasons that property owners and developers resist mitigation programs.

9 For example, Cortner and colleagues (1990:60) state: "People want to be able to choose where they live...many homeowners will continue to create threatening situations by electing to reside in hazard prone zones." M. Lavin (1997:6) adds that "...it is homeowner 'choice' that can ward off misfortune." McKee and colleagues (2004:492) preface their work with this statement: "Thus, drawn to living in the wildland urban interface for a variety of reasons (amenities, privacy, etc.), households can allocate their expenditures across an array of risk reduction and insurance options." The prevailing emphasis on voluntary choice "would seem to preclude the notion that fuels treatments are conducted in the context of scarcity" (D. Rideout 2003:164). Generally, the assumption of voluntary choice is applicable only to the very affluent.
} 
of marginalization. Based on political ecology definitions, such households are vulnerable and at high risk to wildfire.

\section{Methods}

I embraced a multiple method approach - with qualitative and quantitative components - to develop an understanding of marginalization and facilitation as influences on differential risk to wildfire in the White Mountains. I needed local knowledge, which could be generated only through intensive study of people, communities, and institutions. Inquiry involved living and working in the case study communities, working with land managers, synthesizing diverse literatures and collecting and analyzing multiple types of data. The quantitative component involved distributing 1050 structured household surveys door-to-door during summer 2004, of which 563 were returned. ${ }^{10}$ Through going door-to-door every day for two months, I spoke with many people about community, forests, and fire in the White Mountains, which enabled me to better situate the analysis. For the 506 households who responded to the survey and provided address information, I conducted an in-field fire hazard assessment that yielded property measures of wildfire hazard. I incorporated household survey and property hazard assessment data into a geographic information system and integrated secondary data (e.g., property value, year of home construction). I had complete data for 493 households, which I used in regression analyses of household risk (T. Collins 2008; In press).

The qualitative component involved three core methods: participant observation, semi-structured household interviews, and historical/archival analysis. Participant observation entailed living in the study communities over four months, conducting fieldwork in them for two years, and becoming a participant in forest management processes. I have ongoing involvement with local land management institutions. I conducted semi-structured interviews with 33 households who consented through the survey. Interviews ground other data in lived experiences and decision-making processes of households. Historical and archival analysis centered on documenting long-term social and ecological change in the region, which involved consulting the biogeographical/ecological literature, cultural and environmental histories, as well as popular literature about Arizona's White Mountains. Synthesis of historical materials that document social, economic, demographic, ecological, and fire regime changes helps contextualize household risk in terms of the "root causes" and "dynamic pressures" that influence the differentially "[un]safe conditions" in which specific groups of people live (B. Wisner et al. 2004). Quantitative methods enabled identification of multiple influences on household hazard vulnerability. Qualitative methods, including historical synthesis and analysis of interview transcripts and field notes, provided a nuanced understanding of lived experiences and contextual processes that influence differential risk. The synoptic perspective on households-in-context garnered through the multiple method approach enabled a theoretical examination of marginalization and facilitation in reference to the (historical and geographical) production of differential risk to wildfire.

\section{People, landscapes, and fire: history and hazard vulnerability}

Since Anglo-American integration of the U.S. West, successive, and at times, competing forms of capitalism have guided human-environment relations and conflicts (P. Walker 2003; J. McCarthy and J. Guthman 1998; J. McCarthy 2002; W. Robbins 1994; 1999). From the 1870s through the 1950s, resource extraction defined social relations in the White Mountains (T. Sheridan 1995). Demands on the experiential values of forest environs then crystallized as a result of post-WWII affluence, rapid growth of nearby metropolitan areas, the automobile, and an emerging environmental consciousness (H. Rothman 2002). Recreation, tourism and housing development, capitalizing on lifestyle preferences of affluent urbanites, are the basis of the newer, amenity-oriented economy in the White Mountains. In the Mountains today, the 'old' and 'new' economies are both active, and they are usually understood to be in direct conflict. Those prioritizing amenity-use values of forests often oppose the interests of others prioritizing the exchange values of extraction (T. Duane 1999; P. Walker 2003). My historical analysis and fieldwork enabled me to discern three root causes of hazard vulnerability and differential risk that have followed the period of AngloAmerican settlement: an increasingly hazardous fire regime, increasingly hazardous patterns of development, and increasing social inequality and differential vulnerability. These can be traced to how local actors including the ecology - have unevenly articulated with political economic changes. Over time, the facilitation of specific social groups has contributed to ecological degradation, amplified wildfire hazards, and the marginalization of others.

\section{An increasingly hazardous fire regime}

People lived in Southwestern ponderosa pine ecosystems for millennia prior to Anglo-American integration, and this occupation had appreciable ecological effects (M. Samuels and J. Betancourt 1982). Early human interactions with White Mountain environments apparently did not fundamentally alter ecosystem trajectories. By the early 1870s the U.S. began to forcibly control the Apache tribe, who were

10 Unfortunately, I was not able to access the White Mountain Apache Reservation with the structured survey. 
systematically subdued and placed within the reservation system (S. Talbot 1977). This fundamental shift in regional power relations had an immense impact on the human ecology of the White Mountains. The U.S. control of the Apache and the arrival of the railroad in the 1880s announced market integration, facilitating the stabilization of a new, capitalist regime. The traditional Apachería economy was brought to an end; their semi-nomadic and communitarian regime was replaced by the Anglo-American one of sedentary land ownership and competitive individualism. An era dominated by resource extraction for the purpose of AngloAmerican capital accumulation ensued (T. Sheridan 1995).

Due to increased historical resolution, there is greater scholarly consensus over the role of human actions in regional ecological communities during the period of resource extraction. Beginning in the 1870s, industrial scale resource exploitation spread throughout the Southwest (C. Cooper 1960). Integration with the U.S. economy introduced new people and market-driven land uses - including livestock grazing, old-growth tree harvesting, and fire suppression - to the White Mountains, which induced unprecedented and fundamental changes in social and ecological structures.

Grazing led to the stoppage of frequent fires and ultimately contributed to the establishment of dense woody vegetation in the grasslands, woodlands, and forestlands that comprise the region. While intensive grazing was temporarily effective in excluding frequent fire from White Mountain landscapes, it led to changes in these systems that resulted in the development of a more destructive fire regime. Through time overgrazing influences an ecological transition from grassland to more hazardous shrub, woodland, and forest communities (G. Pearson 1942; K. Parker 1945; J. Arnold 1950; T. Johnson 1962; J. Arnold et al. 1964).

With market integration, ponderosa pine became the most valued commercial tree in the Southwest. Logging of the ponderosa pine forests began in the 1870s, and was accelerated by the passing the Timber Cutting Act (1878), which sold parts of the National Forests to people for logging purposes (T. Sheridan 1995). As the market demand for wood products grew, a logging industry developed and supplied an ever increasing volume of timber. T. Sheridan (1995:311) wrote that by the early 1900s, "the USFS wanted to thin the forests of the White Mountains to encourage new growth, and the agency also realized that the expansion of the timber industry was the surest way to increase its own budget and power." Following WWII, a maximum sustainable yield model of 'scientific' forestry that favored even-aged management was institutionalized. Dramatic increases in harvesting and road building occurred in the National Forests. In both on- and off-reservation communities, lumber and pulpwood mills processed the cut from timber contracts secured within the White Mountain Apache Reservation and Apache-Sitgreaves National Forests. During the 1950s and 1960s, community economies were largely dependent on harvesting and processing wood.

Logging has not been as important a driver of ecological change in Southwestern ponderosa pine forests as fire exclusion. It is difficult to practically separate effects of fire exclusion and logging, because with integration, the value of trees as extractable commodities directly influenced the institutionalization of policies of total fire suppression (Figure 2). The Northern Rockies fires of 1910 produced immediate consequences at the national level. Because of the loss of forest reserves, the fires were cited as evidence for the necessity of total fire suppression (S. Pyne 1982). These events served to federalize fire suppression under the aegis of the U.S. Forest Service (USFS). As it was believed that fire contributed to the destruction of forest, watershed, and range resources, fire protection became the principal charge of early foresters.

With the stabilization of a U.S. federal land management regime and resource extraction economy, the Apache were marginalized, Anglo-American ranching and logging industries were facilitated, and regional environments were exploited. Evidence suggests that post-integration human activities, specifically those land uses that excluded fire, are the primary influences on ecological structures and processes in contemporary regional landscapes. Changes in ponderosa pine forests have been the focus of a wealth of ecological research since integration (G. Pearson 1923; 1950; H. Weaver 1951; T. Swetnam and C. Baisan 1996, M. Savage 1991, W. Covington and M. Moore 1994; P. Fulé et al. 1997; A. White 1985; J. Mast et al. 1999, C. Cooper 1960, M. Moore et al. 1999). Studies have offered consistent conclusions and messages about changing forest conditions over the past 100 years:

- Ponderosa pine forests in the Southwest were open, park-like landscapes dominated by grasses, forbs, and shrubs with scattered groups of trees before integration.

- Fire exclusion favored dense ponderosa pine regeneration and eventually led to dramatic increases in tree density, forest floor depth, and fuel loading. While the oldest age classes of trees suffered increasing rates of mortality, open parklands became undifferentiated thickets.

- These dimensions of human-induced change constitute ecological degradation, and have directly resulted in a fire regime characterized by larger and more intense wildfires.

Through commercial land use practices, fires were excluded from the landscape. As the frequent fire regime that structured the region's grasslands, woodlands, and forests before integration was disrupted, wildfire hazards increased. Figure 3A shows what ponderosa pine forest structures were like near McNary 


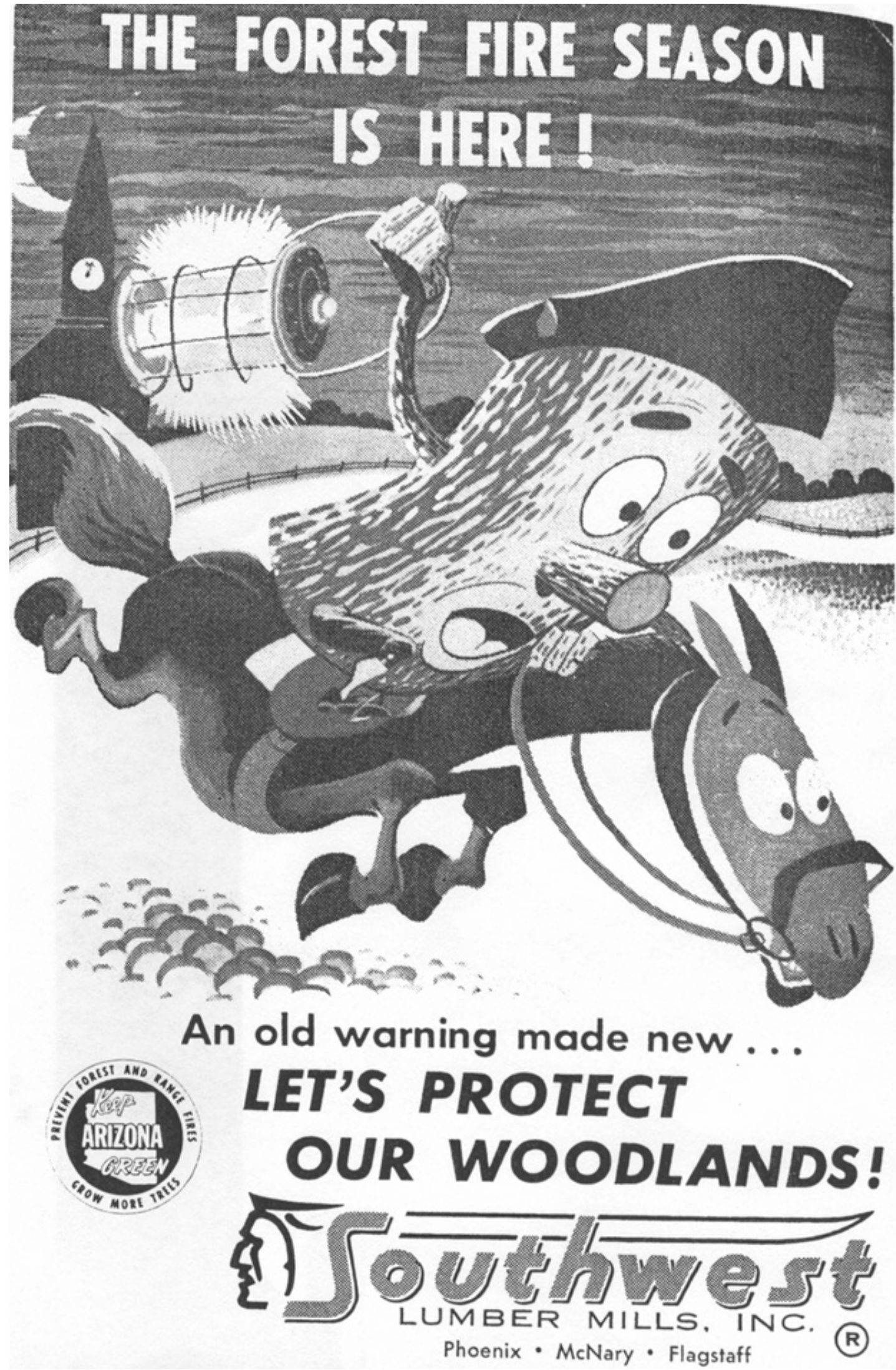

Fig. 2. Southwest Lumber Mills fire prevention message (Source: Arizona Wildlife-Sportsman 1959) 

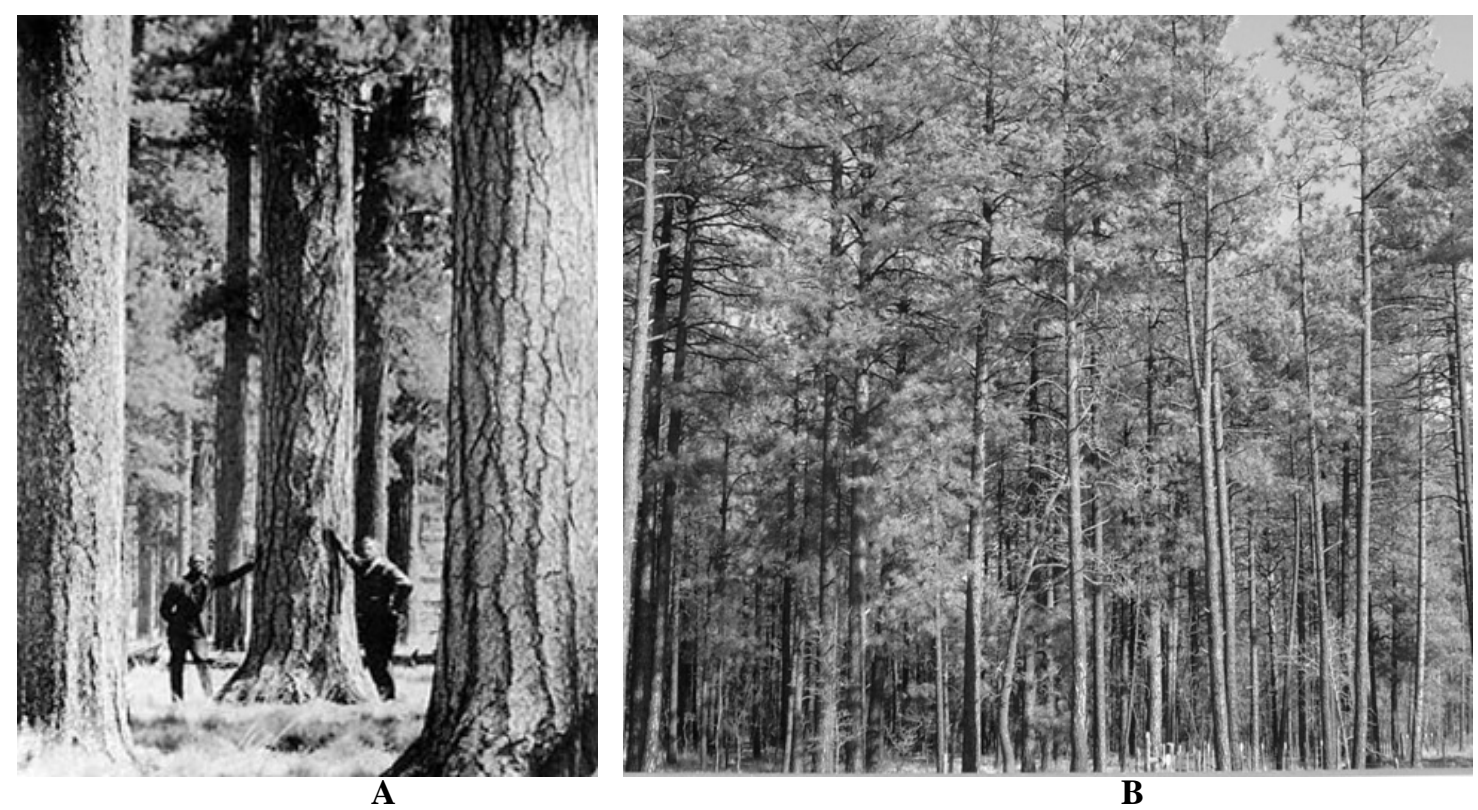

Fig. 3. Forests near McNary, Arizona:

(A) 1925 (Source: Northern Arizona University, Cline Library, Special Collections and Archives, Colorado Plateau Digital Archives); (B) in 2004.

before resource extraction. Within this mature, open forest there is vertical discontinuity between the forest floor and canopy, horizontal separation between individual tree crowns, and abundant grass cover. Such forests are resilient to high magnitude wildfires. Figure 3B depicts how some ponderosa pine forestlands near the town appear today. Within this undifferentiated forest there is a continuous vertical and horizontal arrangement of fuel sources and an absence of grass. Contemporary forest landscapes like this pose an extreme risk of wildfire.

\section{Increasingly hazardous patterns of settlement}

After integration, the livelihood opportunities available to particular groups, and the relative power they were able to harness, became functions of the global marketability of local resources that they were able to control. The marketability of local resources has been an emergent product of global economic trends and shifting socio-cultural orientations. Following WWII, the emergence of environmental values among a burgeoning and increasingly affluent urban population led to a change in federal land management, driving a transition in the White Mountains from a resource extraction to an environmental amenity-oriented economy. ${ }^{11}$ An accompanying demographic shift occurred in the form of urban-to-rural migration. ${ }^{12}$ Ironically, while the urban exodus to White Mountain forests has been fueled by environmental values, it has entrenched efforts to exclude fire from landscapes and complicated forest management efforts and, thus, exacerbated problems of ecological degradation and wildfire hazard. In this process, local resource extractors have been marginalized, amenity migrants from urban areas have been facilitated, and a marginal service economy underclass has grown.

11 The resource extraction economy maintained hegemony in the White Mountains through the 1970s; in the 1980s extractive land uses began to decline in importance as the amenity economy grew rapidly. The growth of amenity valuation is linked with the popular ascendance of environmentalism in the 1960s - a broad cultural shift especially for the post-WWII baby boom generation then coming of working/consuming age. From the 1950s to the 1990s, an economic shift also occurred. In the global market, relative values of regional wood products began to decline as Southeastern U.S. and international regions rose to dominance. While extraction values went into a tailspin, the amenity values of White Mountain forests had been in steady ascension. For capitalists in pursuit of profit, the 1980s represented a time when values of White Mountain forests tipped in favor of amenity development at the expense of resource extraction. By 1990, the Southwestern ponderosa pine timber economy had collapsed due to poor market conditions, a lack of quality timber, legislation intended to protect environmental values, and competition from amenity development.

12 At the national level, the 'rural turnaround' and 'rural rebound' of the 1970s and 1990s saw rapid population growth in U.S. rural communities, especially those rich in natural amenities (C. Beale and K. Johnson 1998; K. Johnson and G. Fuguit 2000; D. McGranahan 1999). 


\begin{tabular}{|c|c|c|c|c|}
\hline \multirow[b]{2}{*}{ Year } & \multicolumn{2}{|c|}{ Mogollon Rim } & \multicolumn{2}{|c|}{ White Mountains } \\
\hline & Population & Housing units & Population & Housing units \\
\hline 1900 & 49,191 & & 17,126 & \\
\hline 1940 & 147,393 & 45,086 & 49,404 & 15,806 \\
\hline 1950 & 173,463 & 51,278 & 57,213 & 13,863 \\
\hline 1960 & 227,619 & 71,791 & 68,432 & 16,496 \\
\hline 1970 & 262,243 & 84,927 & 80,013 & 22,930 \\
\hline 1980 & 390,888 & 164,145 & 119,737 & 47,286 \\
\hline 1990 & 500,149 & 239,110 & 139,249 & 65,698 \\
\hline 2000 & 733,739 & 339,913 & 172,409 & 80,613 \\
\hline
\end{tabular}

Source: US Bureau of the Census, 1995, 1993, 2000

'Mogollon Rim includes Apache, Coconino, Gila, Navajo, Pinal, and Yavapai counties; and White Mountains include Apache and Navajo counties

Table 2. Growth in Mogollon Rim and White Mountain Counties, ${ }^{1} 1900-2000$

Demographic growth within the White Mountains has responded to a striking gradient: the temperate White Mountain ponderosa pine forests lie within short driving time of the burgeoning Phoenix metropolis located in the heat and aridity of the Sonoran Desert. Riding the crest of 1980s and 1990s economic booms, urban money - lubricated by real estate development institutions - has been translated into residential growth. Since 1970 over 200 planned and unplanned subdivision developments within the study area, situated predominantly in forested environments, have been filed with the Navajo County Assessor (Navajo County, 2005). ${ }^{13}$ Population and housing counts have grown steadily, creating the contemporary context of residential wildfire hazard (Table 2).

The acceleration of societal investment associated with environmental amenity development has in effect placed greater fixed values at risk to wildfire (e.g., more homes). Despite technologically equipped and coordinated fire suppression institutions, there are obstacles to fire fighting in White Mountain communities. Many roads do not meet fire safety specifications (LSD 2004; ICC 2003), which makes effective initial attacks on fires and emergency evacuations in the area difficult. ${ }^{14}$ Although the low-density development in some residential landscapes limits total population, it also imposes fire protection problems. Many developed areas are composed of unmanaged timberlands with a scattering of homes. Area fire protection capacities are offset by the dangerous accumulations of fuel between and around structures. In such areas, fire fighters are frequently forced to defend structures instead of attacking the spreading fire, and structures are often difficult to protect due to the large area and number of spot fires that may be burning relative to the number of homes at risk. If a large fire burns into residential areas from surrounding forests, it can easily exceed suppression capabilities under existing fuel conditions. Emergency managers must also deal with evacuation of residents from the hazard area.

Within existing residential landscapes, mitigating hazardous fuels provides the most effective means for reducing fire hazards. Property owners have the responsibility to comply with federal and state statutes and local regulations. No property mitigation regulations existed before the 2002 Rodeo-Chediski fire. While many residents have received educational information with hazard mitigation suggestions, they have been responsible for accessing resources needed for mitigating wildfire hazards. Mitigation requires considerable and continual investments of money and time, which depend on household's differential capacities.

\section{Increasing social inequality and differential vulnerability}

Throughout the era of amenity development, there has been a lack of institutional involvement in promoting safe conditions. Instead of using authority to reduce wildfire risks, state (and market) institutions

13 This figure is based on 2005 Navajo County, Arizona parcel data for the four Assessor's "books" in my study area (i.e., 209-212). I used the number of Assessor's "maps" and data on year of construction as proxies to estimate the number of post-1970 planned and unplanned subdivisions developed.

14 For example, safety specifications call for 3 m clearance of vegetation; accessibility to two-way traffic; width, grade, and curves designed to allow access for large emergency vehicles; and clearly posted, named, and numbered road signs showing traffic restrictions. 
have been instrumental in producing unsafe conditions. For example, federal land exchanges have served the interests of real estate developers, whose increasingly upscale development decisions increase people's exposure to hazards, reinforce socio-economic inequalities, and influence social vulnerability among working class locals. In this process affluent amenity seekers have been facilitated, and working class locals have been marginalized.

Facilitation: the case of Pinetop's country clubs. In 1922, the General Forest Exchange Act authorized the USFS to consolidate forestlands. More recently, public land exchanges have facilitated the shift from extraction-to-amenity. This is encapsulated in the story of the creation of the Pinetop's country clubs. A notable part of this story is how amenity development was initially fueled by wealth accumulated through resource extraction. In the case of the White Mountain Country Club (WMCC), the USFS was petitioned by Southwest Forest Industries to set aside a tract of land for a golf course. "Southwest Forest Industries was interested since it meant a recreational area for their executives working in McNary" (WMCC 2005). In 1954 the USFS agreed "and a large area of beautiful forestland was made available" (WMCC 2005). The transformation from publicly underwritten site of resource extraction to a private sanctuary for nature consumption emerged from within this landscape (WMCC 2005):

The first nine holes were built through multiple volunteer efforts, including major firms leaving heavy equipment on weekends for use on the course. Southwest Forest Industries helped in financing the first clubhouse and lumberman Harold Britt volunteered return use of lumber trucks to bring back supplies free... Through a series of complicated trades between the Country Club, the White Mountain Summer Homes Association, the USFS, and Southwest Forest Industries, 700 acres [283 ha] of USFS land became private property of the homeowners and 166 acres [67 ha] for the golf course was purchased by the Club for $\$ 175,000 \ldots$... By 1967, Joe Clifford, Past President, reported that after 10 years, "We are out of USFS Control"...With the Homeowners Association retaining control of their own roads and the Country Club agreeing to the installation of 'guard gates', the White Mountain Country Club has retained a premier position in the White Mountain area, offering a retreat amid the pines where privacy is one of the premiums and beauty one of the dividends.

From outside the premises, it is difficult to see through the impenetrable thicket that has matured in and around homes, which likely enhances residential "premiums" and "dividends."

R. Baker and others (1988:4-9:7) wrote that land managers "...view the transfer of public lands, previously available for general public use and enjoyment, to exclusive use of a certain segment of the population... as contrary to the general public interest," and added that land exchange is a concern that has "...plagued USFS administrators in the Southwest." While this may be the case, there clearly have been overriding management imperatives. The country clubs' \$2 billion dollar property tax base illuminates existing incentives for local officials to support land exchanges to facilitate amenity development. At the same time, such development exposes far greater economic values to wildfire hazards, providing the USFS an incentive to unload adjacent lands along with the potential for culpability. Public agencies have also been forced to respond by diverting resources into protecting these lifestyle landscapes from fire.

Local articulation and marginalization. Long-time local residents were involved in various ways as actors in the emergence of the amenity economy. Individuals have articulated in different ways with political economic change, and fortunes have generally depended on their capacities to access resources. With the decline of available extraction work, some moved on to a new set of livelihood opportunities offered by the developing amenity economy. Local elites were in many cases able to insert themselves into relatively lucrative amenity-based livelihoods. Most locals, however, have experienced reduced livelihood security. With the decline in extraction over the past 25 years, work options have narrowed and occupational opportunities are now dominated by less secure and lower paying service sector employment. The increasing prevalence of service work has attracted other residents, including an increasingly conspicuous population of non-English speaking Hispanics, a group which comprises a significant proportion of the area's year-round mobile home park population.

On the Reservation, the closure of the large timber mill in McNary and the calculated initiation of a multi-pronged tourism and recreational development program (including a ski resort, recreational lakes, and a resort casino) reflect its transition to an amenity-oriented economy. For residents of McNary, this transition has not been particularly beneficial or smooth. The former mill town is poverty stricken, and the effects of economic bust are clearly visible in the landscape. A few kilometers away, the Hon-dah Resort Casino and 
nearby residential landscapes represent rewards that the White Mountain Apache have reaped through amenity development. $^{15}$

There are important differences in the extraction-to-amenity economic transitions of the White Mountain Apache and off-reservation communities. While they are still dependent on external economic shifts within the bounds of the Reservation, they have largely controlled their transition to an amenity economy. This was not the during the resource extraction era.

While locals' livelihoods, both on and off the Reservation, are often meager in economic terms, they are all dependent either directly or indirectly on outsider visitation. In off-Reservation communities, "free land market" and "benefit through growth" ideologies have undermined any degree of local autonomy that may once have existed. "Economic development" is defined by land speculation and the remote control of local landscapes by economically powerful individuals and collectives. Land speculators, based throughout the U.S. and abroad, have snatched many residential parcels. While some may intend to build vacation or retirement homes, others see land holdings only as numbers in their investment portfolios. In some residential landscapes, more parcels are undeveloped, unmanaged, and hazardous thickets than developed home sites. A related trend is the corporate purchase of land and gradual build-out of large master-planned communities. In these residential settings, creating and enforcing property management rules (i.e., covenants, conditions, and restrictions [CC\&Rs]) are responsibilities of the development corporation. After initially attracting, authorizing, and facilitating corporate developers, governmental authorities sever themselves from any involvement in creating and enforcing land management rules. Incentives for corporations to oversee the management of residential properties are currently lacking.

Accompanying the amenity economy's emergence has been continual pressure on income-poor, land-rich locals to sell swaths of range and forestland to speculators. "Selling-out" is both a tempting and divisive choice facing landed families. The payment of skyrocketing property taxes may be cost prohibitive given the sometimes meager incomes of large area landowners. The sale of land provides economic gains, so some locals, particularly the younger ones, see clear incentives to sell. 'Old-timers' think their younger family members are shortsighted; they see a deeper cultural value to keeping multi-generational homelands in family hands. Such lands are inseparable parts of an identity that cannot be replaced and one that is lost when supplanted by a subdivision.

A question arises in reference to how local people have interacted with broader political economic changes. Have changes marginalized or facilitated local residents? To a certain degree, the answer to this question is open to interpretation. In a positive sense, local elites have been able to adapt their livelihood portfolios in ways that have fostered their own security amidst change. The White Mountain Apache have at least in the last 40 years exerted increasing control over their own economic development. They currently maintain greater autonomy and local control than long-time locals in off-reservation communities.

On the other hand, environmental amenity development has come with far greater costs than benefits for most locals, who have been inserted into subordinate positions within a two-tiered 'mountain playground' economy: as servants to visiting masters. As a result, working class locals have been marginalized. The decline of livelihood opportunities in tandem with rising land values and increasingly upscale residential development have, meanwhile, contributed to a low income housing crisis in the White Mountains (M. Shaffer 2004; C. Reagor 2005). ${ }^{16}$ Locals who wish to remain in the area are hard-pressed in identifying viable alternatives. Some respond by moving away permanently, while those more attached to place may move temporarily, opting for a strategy of return migration after accumulating resources elsewhere. Both responses appear as reflections of marginalization. It is clear that land speculation, upscale development, and property value increases associated with amenity development have contributed to increasing social vulnerability among locals.

In sum, political economic transformation in the White Mountains has marginalized working class locals and facilitated colonization by affluent amenity seekers (and land speculators) from metropolitan areas. Meanwhile, ecological degradation, also a byproduct of political economic transformation, has translated into increasing fire hazard. The specific built-environmental characteristics of amenity development - exhibiting exclusivity, dense forests, and a preference for naturalness- have further amplified wildfire hazards and placed vulnerable working class locals and their livelihoods at greater risk.

\footnotetext{
15 Table 1 documents the striking socioeconomic disparities between McNary, where the 1999 median household income was below $\$ 5,000$, and Hon-dah, where it exceeded $\$ 45,000$.

16 An attempt by the Town of Pinetop-Lakeside to check the exclusive trajectory of residential development and make it possible to retain and attract full-time, middle income residents (e.g., teachers, nurses, police) was recently thwarted (M. Shaffer 2004). According to the Mayor, the attempt "really angered a lot of people, and they did a referendum and repealed it on November 2 [2004]. There's a prevailing opinion that anything even similar to apartments is just slums and bad people" (quoted in M. Shaffer 2004). He added, "Unless we can change attitudes, it's going to become an even richer man's paradise" (quoted in M. Shaffer 2004).
} 


\section{Institutions, households and the production of differential risk}

Distinctive types of residential landscapes combine particular groups of people, ecological communities, and built environments in 'place'. The combinations of characteristics that define residential landscapes also create patterns of differential risk, most clearly between amenity seeking migrants and the working class. I discuss how institutions have guided the production of differential hazard vulnerability in the White Mountains through the residential development process. Drawing on my field experience, and statistical and interview analysis results, I now introduce a typology of residential landscapes. I then explain how processes of marginalization and facilitation have concatenated differential risk in residential landscapes.

\section{Institutions, social protection, and endangerment}

My results suggest that institutional structures are the most important influences on differential household risk (T. Collins 2005b). Relationships between households and hazards are not direct. There are intervening variables involved, most importantly those institutions that structure aspects of our existence. Real estate interests and planning commissions, for example, act to mask the "objective" nature of hazards (A. Kirby 1990:6). Developers capitalize by building subdivisions within attractive and fire-prone ponderosa pine forests, and planning commissions rationalize these choices. In such situations, a prospective resident is left to evaluate the hazard associated with a home site through a dual filter - the first linked to the market, the second to the state. My analysis reveals that the residential setting (e.g., single family subdivision, mobile home park, apartment complex, condominium, gated enclave, isolated dwelling) is the most important influence on household hazard exposure ( $T$. Collins In press). Residential settings represent the landscapes co-produced by real estate interests and land use decision-makers. These provide a limited set of residential options to households, whose choices are conditioned by values and means.

My results demonstrate that certain forms of development (mobile home parks and isolated cabins) powerfully increase hazard exposure, while others (apartments and condos) decrease it (T. Collins In press). Differential household hazard exposure is influenced greatly by the inadequate and uneven application of social protection by state and market institutions. Fire fighting and fire insurance institutions are the foundation of the conventional approach to protection against fire hazards, yet these programs are unevenly applied and produce externalities (e.g., hazardous residential behavior and risk transference). Only in recent years has hazard mitigation been considered by land managers and policy-makers as an essential part of 'sustainable' social protection. The most important influences on hazard mitigation relate to household socioeconomic characteristics: lower income and renting households are constrained in mitigation (T. Collins 2008). This reflects how hazard mitigation in the White Mountains has been designated to the realm of self protection, severed by institutions from the domain of social protection.

Due to strong local pro-growth and private property rights ideologies, approaches to preventing fire hazards via restrictive land use planning are typically viewed unfavorably. With accelerating real estate development targeting the region's most hazardous ponderosa pine environments - facilitated by state institutions - sole reliance on a household mitigation will not be an effective means of reducing fire hazards. My results reveal that despite the recent management emphasis on household level mitigation, it is not a powerful influence on hazard exposure (T. Collins 2005b). This suggests that reducing fire hazards depends less on mitigation and more on patterns of development that expose households to practically irremediable hazards. State and market institutions play a dual role in producing hazard vulnerability by facilitating the production of acute residential fire hazards while neglecting to provide an adequate framework for social protection of vulnerable people against hazards. In White Mountain communities, the role of these institutions involves more than the inadequate provision of social protection; it involves the active endangerment of vulnerable social groups.

\section{The concatenation of differential risk in residential landscapes}

Analyzing vulnerability requires that particular forms of (un)safe conditions be considered in relation to specific hazards (B. Wisner et al. 2004:54). Across White Mountain communities, political economic transformation has contributed to the concatenation of differential vulnerability across residential landscapes. The concept of concatenation underscores how vulnerability emerges through processes that produce associations among multiple social and biophysical attributes. Through the marginalization of the extraction-based economy and facilitation of the amenity-oriented economy, differentially (un)safe conditions have been structured between livelihood and lifestyle residential landscape types, which are characterized by varying degrees of livelihood security, differing views on nature (i.e., environmental values), and ranging levels of hazard exposure (see Figures $4 \mathrm{a}$ and $4 \mathrm{~b}$ ).

Institutions have facilitated amenity development and urban-to-rural migration, which have contributed to socioeconomic bifurcation, escalating living costs, and hazardous residential growth in landscapes subject to increasingly destructive fires. USFS land swaps have privatized amenity-rich lands once in the public domain, and such exchanges have supplied the template upon which real estate developers 


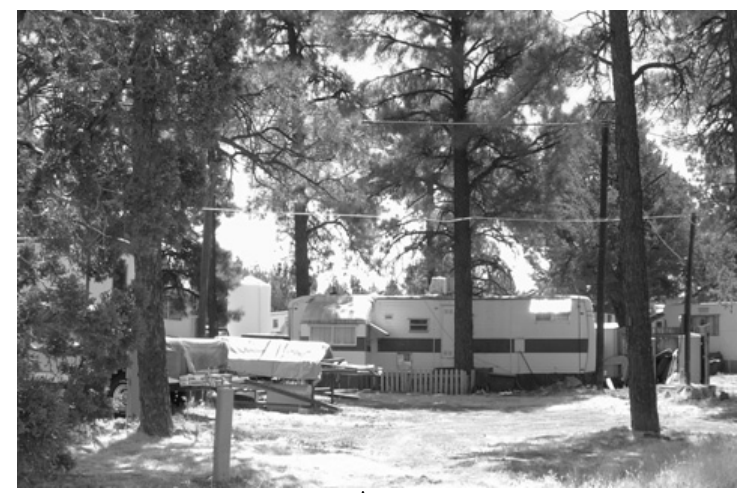

A

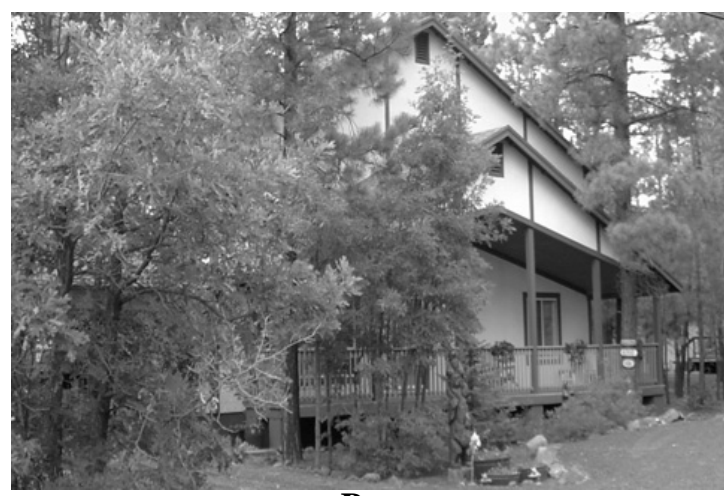

B

Fig. 4. A typology of residential landscapes: (A) livelihood - Show Low year-round mobile home park; (B) lifestyle - Pinetop Country Club

have constructed a constellation of increasingly exclusive lifestyle landscapes through time. Affluent residents in lifestyle landscapes confidently rely on the social protection institutions of the state and market fire suppression and fire insurance - in their desire to pursue pleasure and avoid pain. Institutional rearrangements that facilitate (i.e., bolster the security of) affluent residents of these lifestyle landscapes in the face of hazards, simultaneously marginalize working class locals who reside in livelihood landscapes.

With the decline in livelihood security among working class locals, capacities for self protection have been reduced. While state and market institutions have contributed to their endangerment (as opposed to their protection), institutions of civil society provide the primary means for working class locals to access social protection. Mutual aid accessed through social networks and local collective action provides an important form of social protection for households in livelihood landscapes.

The amenity economy demands a service underclass and marginalizes middle class workers. It produces a bifurcated local economy and spatially segregates social groups within the two general types of residential landscapes. There is far greater livelihood insecurity among locals residing in livelihood landscapes because most are either unemployed or underemployed in the service economy. In contrast, there is generally a high degree of livelihood security within lifestyle landscapes, especially among those with significant assets. ${ }^{17}$ In comparison to working class locals, amenity migrants stand to lose less in hazard events.

There are also fundamental differences in views on nature between the two groups. People in lifestyle landscapes view the White Mountain forests as a repository of naturalness values (p)reserved for their consumption. While full-time amenity migrants may have strong identity-based lifestyle attachments to the local environment, they do not depend on local forests for sustenance. In contrast, the incomes of working class locals depend on the White Mountain forests, whether directly through logging or indirectly through the amenity economy. While they also appreciate the beauty of the White Mountains, working class locals who occupy livelihood landscapes typically view forests as the basis of their livelihood - an economic resource they must carefully utilize and one that they could lose in the event of catastrophic wildfire.

Biophysical hazard mechanisms do not differ between livelihood and lifestyle landscapes, but the risks they pose do differ. This is due to countervailing tendencies in the roles of values (i.e., views on nature) and means (i.e., livelihood security) as influences on self protection and social protection. The collective environmental values of affluent ex-urbanites - in tandem with the facilitating machinations of state and market institutions - have produced lifestyle landscapes amidst attractive and hazardous ponderosa pine forests. Development pressure has driven up property values in the land market, and it has excluded working class locals. Within such lifestyle landscapes, acute wildfire hazards are minimized by generous provisions of socialized fire insurance and public fire suppression resources. These mechanisms facilitate self protection for those in lifestyle landscapes and enable amenity migrants to materialize their desires to consume nature and externalize risks.

Although risks are transferred to broad segments of society (e.g., through insurance premiums and federal taxes), they are primarily placed on working class locals in adjacent livelihood landscapes in the

17 Seasonal mobile home parks are the only lifestyle landscapes in which livelihood insecurity is of concern; by providing the region's only low-cost lifestyle options, they target and attract amenity migrants on fixed incomes. Even for relatively marginal amenity migrant subpopulations, local investments - typically limited to mobile homes - usually represent a minor component in overall livelihood portfolios. 
forms of amplified fire hazards and reduced livelihood security. Residents of livelihood landscapes are often uninsured and underserved by public fire suppression. Locals with reduced livelihood security - like the poor of McNary and low income renters in year-round mobile home parks - also have reduced capacities to self protect through mitigation. Social inequalities structured by laws and policies, particularly those pertaining to renter-landlord arrangements and immigrant status, cumulatively disadvantage low/fixed income renters and Hispanic immigrants. 18

Viewing these results synoptically, broad scale ecological patterns, state and market institutions, and residents' means and environmental values appear to recursively structure patterns of differential risk across residential landscapes. These emergent patterns have developed in response to uneven political economic changes that have shaped imperatives of human land use in the White Mountains. The active role of state and market institutions in providing social protection for affluent amenity migrants in lifestyle landscapes while endangering working class locals in livelihood landscapes exemplifies the mutually constitutive processes of facilitation and marginalization.

\section{Conclusion}

In this paper, I have considered the applicability of marginalization theories, developed in studies of Third World hazard vulnerability, to conditions and processes in First World human-environments. The concept of marginalization offers powerful lens for understanding the political ecology of risk. Informing local and global understandings of human-environment relations, however, requires more nuanced concepts. Limitations to marginalization can be addressed by considering the mutually constitutive concept of facilitation. This will permit scholars to more clearly recognize and more effectively dissolve distinctions between Third and First World political ecologies.

The concept of marginalization is limited by an inherent bias in environmental hazards research of all stripes: that environments present primarily hazards - and secondarily rewards - to humans. This has led to recognition of the importance of integrating "the analysis of hazard and the analysis of reward within a common research paradigm" (K. Mitchell 1990:160). It must be recognized that human valuations of the environment are central to decision-making regarding risks, in part because sources of reward (e.g., trees) and hazard (e.g., fuels) are often not easily separable. ${ }^{19}$ For example, decisions to reduce wildfire hazards necessitate removing associated amenities in the White Mountains. As one resident told me, "You can't take all the trees down, or you wouldn't have any forest [laughter]." For capitalists, the hazard and amenity (i.e., reward) attributes of such landscapes cannot be materially separated as part of an accumulation strategy. Accumulation necessitates the enlistment of state and market agents to institutionally minimize the hazards associated with amenity landscapes, thus facilitating reliable growth into the future. For the political ecologist, applying concepts of marginalization and facilitation to the examination of environmental risks and rewards - while focusing the role played by institutions in the transference of risks - helps sharpen understanding.

In directing our attention to the institutional mechanisms that enable society's most powerful to externalize risks in their pursuit of environmental gain - often at the expense of broader societal interests and the integrity of ecological systems - facilitation offers a conceptual complement to marginalization and broadens the political ecology frame. Paul Robbins (2002) emphasized the importance of examining institutional influences on First World political ecologies. Institutions are instrumental in relocating and shaping experiences of risk across scales, and thus are critical to understanding processes of marginalization and facilitation (S. Cutter 2003, C. Moser 1998, R. Kasperson et al. 2001). ${ }^{20}$ In considering the role of

18 Renters are legally prohibited in mitigating hazards where they live and are vulnerable to displacement in a hazard event; renters' marginality is compounded by their typically low incomes, reserved assets, and lack of fire insurance. This bundling of disadvantages applies to legal and illegal Hispanic service workers, whose vulnerability has been intentionally compounded by the state. The political discourse that has emerged in the U.S. over 'illegal aliens' restricts entitlements for undocumented immigrants and influences legal immigrants to avoid federal programs that they are entitled to use for fear of jeopardizing their residency status (F. Collins 1997; B. Bolin with L. Stanford 1998). Current Federal Emergency Management Act (FEMA) regulations deny all forms of federal resources and make subject to deportation those who cannot prove they are legal residents in the U.S. (B. Wallrich 1996). Hispanics with limited English language proficiency are further limited in accessing resources.

19 In some cases hazards and rewards may be separated as part of an accumulation strategy. For example, commodities are produced and distributed for profit (and supposedly to benefit diffuse segments of society), while hazardous industrial pollutants are released and concentrate near points of production. Thus, lives of local residents are imperiled and not enriched by industrial production facilities (unless they provide a source of livelihood), which for the purposes of analysis may be represented exclusively as hazards.

20 Moser (1998), Cutter (2003), and Kasperson et al. (2001) argue that understanding the mechanisms of risk transference is key to choosing measures for vulnerability analysis and identifying effective policy interventions. Crossscale assessments can illuminate the broader structure of risk causation, build bridges for management and policy, strengthen assessment capacities at different scales, create alternative framings of the environmental problem, and produce knowledge that is more integrative, legitimate, and usable (C. Moser 1998:6-7). Susan Cutter (2003:7) poses a 
institutions in marginalization and facilitation, one seeks to identify mechanisms through which social systems (re)distribute, export, and concentrate risks among individuals, groups, places, and ecosystems. Market, state, and civic institutions directly mediate hazard vulnerability by transferring risks (i.e., allocating costs and benefits) in at least two ways: through the provision of social protection and by determining rules of resource access and control. Institutions are sources of power in producing rules concerning local forest usage, and shaping differential experiences of risk. For example, the USFS is a venue for contestation amongst divergent groups with sometimes competing (and complementary) visions and interests. Winners of these contests harness power in the process of USFS rulemaking. With the emergence of amenity development, the dominant forms of social protection provided by risk management institutions (fire insurance and fire fighting) have increased the security of affluent amenity seekers; but they have also amplified wildfire hazards and reduced ecological resilience, which represents the transfer of risks from privileged groups to society and ecosystem. This reveals basic dimensions of power in relationships among people, forests, and fire.

In addition, the concept of marginalization as originally formulated is informed by a spatial model that stresses relations between a dominant First World and subordinate Third World. Since the original theoretical expositions of marginalization, scholars have embraced multi-scalar socio-spatial notions. While measurable differences in hazard vulnerability exist between rich and poor nations (B. Wisner et al. 2004), global models tend to obfuscate linkages with local processes, which are characterized by complex webs of human-environment interactions. Patterns of development and underdevelopment may be relationally produced across a range of geographical scales (from global to local) in response to prevailing social inequalities and the dominant ideological and political economic imperatives of land use. Understanding and explaining patterns of differential risk necessitates greater attention to cross-scale linkages.

I conceive of marginalization and facilitation as neither mutually exclusive nor necessarily geographically determinate processes. In other words, these processes operate at a range of scales and may together influence the production of divergent vulnerability profiles between (and within) households, communities, and nations. By applying these concepts in political ecological study, we can better understand varying socio-environmental experiences in the context of political economic change. To demonstrate how, I introduced the case of urban wildfire hazards in Arizona's White Mountains. Based on the assumptions of residential affluence and free choice made in previous studies, scholars have focused primarily on processes that facilitate affluent amenity seekers. This narrow focus has obscured the history of underdevelopment and the production of social vulnerability in the rural U.S. West. In the White Mountains, patterns of underdevelopment have been relationally produced in response to the regional trajectory of political economic change. Processes of facilitation and marginalization have together shaped the emergence of the amenity economy and the corresponding decline of the extraction economy, and have inscribed emergent patterns of differential risk at the geographical scale of residential landscapes.

Finally, marginalization and facilitation provide a dual optic for recognizing and dissolving distinctions between First and Third World political ecologies. For example, scholars have observed qualitative differences in social relationships to hazards between the First and Third Worlds. In the Third World, processes of marginalization often force the poor to live and work in hazardous places (Hewitt 1997). With the greatly increased availability of property insurance, financial credit and state-sponsored social protection in the First World, privileged groups are able to negotiate hazards in ways not possible in the Third World (B. Bolin with L. Stanford 1998:45). In contrast to Third World elites, who tend to avoid hazardous locations, elites in the First World often choose to live in hazardous settings because they have the distinct capacity to socialize costs of their self protection via institutional facilitation.

To further dissolve uncritical First/Third World dualisms, it is important to note that processes of marginalization and facilitation may produce differential risks in any context. While there are vast differences in aggregate wealth between nations of the First and Third Worlds, aggregate wealth is less important than the unequal social distribution of wealth in producing differential risks (N. Adger 2000; B. Bolin with L. Stanford 1998). While the prevalence and qualitative characteristics of hazard vulnerability differ between the First and Third Worlds, risks may be unevenly distributed anywhere based on prevailing social inequalities (B. Bolin with L. Stanford 1998; W. Peacock et al. 1997; B. Wisner 1993). Vast differences in assets and entitlements are found not only between the two Worlds, but within countries, regions, and communities of the North and South. In the First World, such differences are becoming widened as economic restructuring and neoliberal economic policies are enriching the already wealthy, while reducing social protections and entitlements for the poor (D. Harvey 2000). As these political economic changes cascade across scales, they are institutionalized in a manner that both reflects and reinforces social inequalities and produces differential risks. In sum, the concepts of marginalization and facilitation provide

series of questions: "What is the role of our current practices and public policies in fostering the relocation of risk? In what ways do our current policies transfer the risk burden from one individual to another or from one place to another? ... How do federal policies, initially aimed at risk and hazard reduction...put more people and places at risk? Many of our public policies transfer the risk to future generations ..." She concludes that vulnerability analysis "can help guide us to answers on the temporal and spatial transference of risk." 
heuristics for historically and geographically situating political ecologies of risks, hazards, and disasters anywhere.

\section{References Cited}

Adger, $\mathrm{N}$.

2000. Social and ecological resilience: are the related? Progress in Human Geography 24(3):347364.

Arnold, J.

1950. Changes in ponderosa pine bunchgrass ranges in northern Arizona resulting from pine regeneration and grazing. Journal of Forestry 48:118-126.

Arnold, J., D. Jameson, and E. Reid.

1964. The pinyon-juniper type of Arizona: effect of grazing, fire, and tree control. USDA Forest Service Production Research Report 84:1-28.

Baker, R., R. Maxwell, V. Treat, and H. Dethloff.

1988. Timeless heritage: a history of the Forest Service in the Southwest. FS-409. Washington, DC:

Bassett, T. U.S. Department of Agriculture, Forest Service.

1988. The political ecology of peasant-herder conflicts in the northern Ivory Coast. Annals of the Association of American Geographers 78(3):453-472.

Beale C., and K. Johnson.

1998. The identification of recreational counties in nonmetropolitan areas of the USA. Population Blaikie, P. Research and Policy Review 17:37-53.

1985. The Political Economy of Soil Erosion in Developing Countries. New York: Longman Scientific and Technical.

Blaikie, P., and H. Brookfield, eds. 1987. Land Degradation and Society. London: Methuen.

Bolin, B., and L. Stanford.

1998. The Northridge Earthquake: Vulnerability and Disaster. London: Routledge.

Breshears, D., N. Cobb, P. Rich, K. Price, C. Allen, R. Balice, W. Romme, J. Kastens, M. Floyd, J. Belnap, J.

Anderson, O. Meyers, and C. Meyer. 2005. Regional vegetation die-off in response to global-change-type drought. Proceedings of the National Academy of Sciences 102(42):15144-15148.

Brogden, M., and J. Greenberg.

2003. A fight for the West: a political ecology of land use conflicts. Human Organization 62(3):289-298.

Bryant, R., and S. Bailey.

Chambers, R. 997. Third World Political Ecology. London: Routledge.

Cheng, $\mathrm{A}$.

1989. Editorial introduction: vulnerability, coping, and policy. IDS Bulletin 21:1-7.

2003. Fire social science research: opening remarks. In Fire, Fuel Treatments, and Ecological Restoration: Conference Proceedings, ed. P. Omi, and L. Joyce, 209-211. USDA Forest Service Proceedings RMRS-P-29.

Cohen, J.

2000. Preventing disaster: home ignitability in the wildland-urban interface. Journal of Forestry

Collins, F. 98(3):15-21.

1997. Social and economic changes that will affect disaster recovery: what voluntary agencies Collins, T. should consider. Unpublished report, Richmond, CA: NorCal VOAD.

2005a. Households, forests, and fire hazard vulnerability in the American West: a case study of a California community. Global Environmental Change B: Environmental Hazards 6(1):23-37.

Collins, $\mathrm{T}$.

2005b. The production of hazard vulnerability: the case of people, forests, and fire in Arizona's White Mountains. Unpublished doctoral dissertation: Department of Geography, Arizona State University, Tempe.

Collins, T.

2008. What influences hazard mitigation? Household decision making about wildfire risks in Collins, T.

Arizona's White Mountains. The Professional Geographer 60(4):508-526.

In press. Influences on wildfire hazard exposure in Arizona's high country. Society and Natural Resources. 
Cooper, C.

1960. Changes in vegetation, structure, and growth of southwestern ponderosa pine forests since white settlement. Ecological Monographs 30(2):129-164.

Cortner, H., P. Gardner, and J. Taylor.

1990. Fire hazards at the urban-wildland interface: what the public expects. Environmental Management 14:57-62.

Covington, $\mathrm{W}$.

2003. Restoring ecosystem health in frequent-fire forests of the American West. Ecological Restoration 21(1):7-11.

Covington, W., and M. Moore.

1994. Southwestern ponderosa pine forest structure and resource conditions: changes since Euro-

Cronon, W. American settlement. Journal of Forestry 92:39-47.

1996. Introduction: in search of nature. In Uncommon ground: Rethinking the Human Place in Cutter, S. Nature, ed. W. Cronon, 23-66. New York: W.W. Norton and Co.

2003. The vulnerability of science and the science of vulnerability. Annals of the Association of American Geographers 93(1):1-12.

1999. The Ecology of Fear: Los Angeles and the Imagination of Disaster. New York: Metropolitan.

Doak, S., and J. Kusel.

1996. Well-being in forest dependent communities, part II: a social assessment focus. In Status of the Sierra Nevada: Volume II, Assessments and Scientific Basis for Management Options, 375-400.

Duane, $\mathrm{T}$. Davis, CA: University of California Davis Press.

1999. Shaping the Sierra: Nature, Culture, and Conflict in the Changing West. Berkeley, CA: University of California Press.

Fulé, P., W. Covington, and M. Moore.

1997. Determining reference conditions for ecosystem management of southwestern ponderosa pine Fulton, W. forests. Ecological Applications 7(3):895-908.

1995. Burn, California, Burn. Planning 61(6):4-9.

Gardner, P., and L. El-Abd.

1984. A study of the impacts of severe wildland fires and disaster relief programs on homeowners residing in the wildland-urban interface. Riverside, CA: USDA Forest Service Tech. Completion Rep.

General Accounting Office.

1998. Western forests: catastrophic fires threaten resources and communities. Report GAO T-

Gomez, A. RCED-98-273.

2001. Industry and Indian self-determination: Northern Arizona's Apache lumbering empire, 18701970. In Forests Under Fire: A Century of Ecosystem Mismanagement in the Southwest, ed. C. Huggard, and A. Gomez, 3-40. Tucson, AZ: University of Arizona Press.

Harvey, D.

2000. Spaces of Hope. Berkeley: University of California Press.

Hemenway, D.

1987. Private insurance as an alternative to protective regulation: the market for residential fire insurance. Policy Studies Journal 15(3):415-440.

Hewitt, K, ed.

1983a. Interpretations of Calamity from the Viewpoint of Human Ecology. Boston, MA: Allen and Unwin.

Hewitt, K.

1983b. The idea of calamity in a technocratic age. In Interpretations of Calamity from the Viewpoint

Hewitt, K. of Human Ecology, ed. K. Hewitt, 3-32. Boston, MA: Allen and Unwin.

Hodgson, R.

1997. Regions of Risk: A Geographical Introduction to Disasters. Essex, U.K.: Longman.

1995. Strategies for and barriers to public adoption of fire safe behavior. In The Biswell Symposium: Fire Issues and Solutions in Urban Interface and Wildland Ecosystems, ed. D. Weise, and R. Martin, 93-98. USDA Forest Service General Technical Report PSW-GTR-158.

Insurance Services Office, Inc. 1997. The Wildland-Urban Fire Hazard. New York: ISO Insurance Issue Series.

ICC (International Code Council).

2003. International Urban-Wildland Interface Code. 
Johnson, T.

1962. One seed juniper invasion of northern Arizona grasslands. Ecological Monographs 32:187207.

Johnson, K., and G. Fuguitt.

2000. Continuity and change in rural migration patterns, 1950-1995. Rural Sociology 65(1):27-45.

Kasperson, R., J. Kasperson, and K. Dow.

2001. Introduction: Global Environmental Risk and Society. In Global Environmental Risk, ed. J. Kasperson, and R. Kasperson, 1-48. New York: United Nations University Press.

Kates, R., and V. Haarmann.

Kirby, A.

1992. Where the poor live: are the assumptions correct? Environment 34:4-28.

1990. On social representations of risk. In Nothing to Fear: Risks and Hazards in American Society, ed. A. Kirby, 1-16. Tucson, AZ: University of Arizona Press.

Kruger, L., S. Agrawal, M. Monroe, E. Lang, K. Nelson, P. Jakes, V. Sturtevent, S. McCaffrey, and Y. Everett.

2003. Keys to community preparedness for wildfire. In Homeowners, Communities, and Wildfire: Science Findings from the National Fire Plan, ed. P.L. Jakes, 10-17. USDA Forest Service Gen. Tech. Rep. NC-231.

Kusel, J.

1996. Well-being in forest dependent communities, part I: a new approach. In Status of the Sierra Nevada: Volume II, Assessments and Scientific Basis for Management Options, 361-374. Davis, Lavin, M. CA: University of California Davis Press.

Limerick, $\mathrm{P}$

1997. Managing fire risk to people, structures, and the environment. Fire Management Notes 57(4):4-6.

1989. The Legacy of Conquest: The Unbroken Past of the American West. New York: W.W. Norton and Company.

Liverman, D.

2001. Vulnerability to global environmental change. In Global Environmental Risk, ed. J. Kasperson, and R. Kasperson, 201-216. New York, NY: United Nations University Press.

LSD (Logan Simpson Design).

2004. Community Wildfire Protection Plan for At-Risk Communities of the Sitgreaves National

Lynn, K. Forest in Apache, Coconino, and Navajo Counties. Tempe, AZ: Logan Simpson Design.

Mast, J., P. Fulé, M. Moore, W. Covington, and A. Waltz. 1999. Restoration of presettlement age structure of an Arizona ponderosa pine forest. Ecological Applications 9(1):228-239.

McCaffrey, S. 2004. Thinking of wildfire as a natural hazard. Society and Natural Resources 17(6):509-516.

McCarthy, J.

2002. First World political ecology: lessons from the Wise Use movement. Environment and Planning A 34(7):1281-1302.

McCarthy, J., and J. Guthman.

1998. Nature and capital in the American West: introduction. Antipode 30:67-72.

McGranahan, D.

1999. Natural amenities drive rural population change. Agricultural Economic Report No. 781. Washington, DC: USDA Economic Research Service.

McKee, M., R. Berrens, M., Jones, R. Helton, and J. Talberth.

2004. Using experimental economics to examine wildfire insurance and averting decisions in the

Mitchell, J. wildland-urban interface. Society and Natural Resources 17(6):491-508.

1990. Human dimensions of environmental hazards. In Nothing to Fear: Risks and Hazards in American Society, ed. A. Kirby, 131-175. Tucson, AZ: University of Arizona Press.

Moore, M., W. Covington, and P. Fulé.

1999. Evolutionary environment, reference conditions, and ecological restoration: a southwestern Moser, C. ponderosa pine perspective. Ecological Applications 9(4):1266-1277.

1998. The asset vulnerability framework: reassessing urban poverty reduction strategies. World Development 26(1):1-19. 
Navajo County.

2005. Parcel data (obtained online). http://www.co.navajo.az.us/theCountyRecorder/DataSearch/Searchhome.aspx [accessed 19 June 2005].

Nelson, K., M. Monroe, J. Johnson, and A. Bowers.

2003. Public perceptions of defensible space and landscape values in Minnesota and Florida. In Homeowners, Communities, and Wildfire: Science Findings from the National Fire Plan, ed. P.L. Jakes, 55-62. USDA Forest Service Gen. Tech. Rep. NC-231.

O'Keefe, P., K. Westgate, and B. Wisner. 1976. Taking the 'naturalness' out of 'natural disaster.' Nature 260:566-567.

Oliver-Smith, A., and S. Hoffman, eds. 1999. The Angry Earth: Disaster in Anthropological Perspective. London: Routledge.

O'Riordan, T., and P. Timmerman. 2001. Risk and imagining alternative futures. In Global Environmental Risk, ed. J. Kasperson, and Parker, K R. Kasperson, 429-450. Tokyo: United Nations University Press.

1945. Juniper comes to the grasslands: why it invades southwestern grassland - suggestions on control. American Cattle Producer 27:12-24, 30-32.

Peacock, W., B. Morrow, and H. Gladwin, eds. Pearson, G. 1997. Hurricane Andrew: Ethnicity, Gender and the Sociology of Disasters. London: Routledge.

1923. Natural reproduction of western yellow pine in the Southwest. U.S. Forest Service Bulletin No. 1105

Pearson, G.

1942. Herbaceous vegetation a factor in regeneration of ponderosa pine in the Southwest. Ecological Monographs 12:313-338.

Pearson, G. Peluso, N.

1950. Management of ponderosa pine in the Southwest. U.S. Agriculture Monograph 6.

1992. Rich Forests, Poor People: Resource Control and Resistance in Java. Berkeley: University of California Press.

Pyne, S.

1982. Fire in America: A Cultural History of Wildland and Rural Fire. Princeton, NJ: Princeton University Press.

Pyne, S.

Reagor, C.

2003. Tending Fire: Coping with America's Wildland Fires. Washington, D.C.: Island Press.

Rideout, D.

2005. Affordable housing is a statewide problem. The Arizona Republic, 11 September.

2003. Social sciences and the economics of moderation in fuels treatment. In Fire, Fuel Treatments, and Ecological Restoration. Conference Proceedings, eds. P. Omi and L. Joyce, 163-166. USDA Forest Service Proceedings RMRS-P-29.

Ring, R.

Robbins, $\mathrm{P}$

2003. A losing battle. High Country News 35(10):8-15.

Robbins, $\mathrm{P}$.

2004. Political Ecology: A Critical Introduction. Malden, MA: Blackwell Publishing.

2002. Obstacles to a First World political ecology? Looking near without looking up. Environment and Planning A 34(8):1509-1513.

Robbins, P, A. Polderman, and T. Birkenholtz.

2001. Lawns and toxins: an ecology of the city. Cities 18(6):369-80.

Robbins, W.

1994. Colony and Empire: The Capitalist Transformation of the American West. Lawrence: University of Kansas Press.

Robbins, W.

1999. In pursuit of historical explanation: capitalism as a conceptual tool for knowing the American

Rodrigue, C. West. Western Historical Quarterly 30:277-293.

1993. Home with a view: chaparral fire hazard and the social geographies of risk and vulnerability.

Rothman, $\mathrm{H}$ The California Geographer 33:29-42.

2001. Seeing the forest not for the trees: the future of Southwestern forests. In Forests Under Fire: A Century of Ecosystem Mismanagement in the Southwest, ed. C. Huggard, and A. Gomez, 287-298. Tucson, AZ: The University of Arizona Press. 
Samuels, M., and J. Betancourt.

1982. Modeling the long-term effects of fuelwood harvest on pinyon-juniper woodlands.

Savage, $M$. Environmental Management 6:505-515.

1991. Structural dynamics of a Southwestern pine forest under chronic human influence. Annals of the Association of American Geographers 81(2):271-89.

Schroeder, R.

2005. Debating the place of political ecology in the First World. Environment and Planning A 37(6):1045-1048.

Schroeder, R., K. St. Martin, and K. Albert.

Shaffer, M. 2006. Political ecology in North America. Special issue Geoforum 37(2).

Sheridan, $\mathrm{T}$.

2004. Mountain-high home prices squeezing out middle class. The Arizona Republic, 26 November.

Sheridan, $\mathrm{T}$

1995. Arizona: A History. Tucson: University of Arizona Press.

2001. Cows, condos, and the contested commons: the political ecology of ranching on the ArizonaSonora borderlands. Human Organization 60(2):141-152.

Susman, P., P. O'Keefe, and B. Wisner.

1983. Global disasters, a radical interpretation. In Interpretations of Calamity from the Viewpoint of Human Ecology, ed. K. Hewitt, 263-283. Boston, MA: Allen and Unwin.

Swetnam, T., and C. Baisan.

1996. Historic fire regime patterns in the southwestern United States since AD 1700. In Fire Effects in Southwestern Forests: Proceedings of the Second La Mesa Fire Symposium, ed. C. Allen, 11-32. USDA Forest Service General Technical Report RM-GTR-286.

Talbot, S.

1977. The myth of Indian economic and political incompetence: the San Carlos case. Southwest Economy and Society 2(Spring):3-46.

U.S. Bureau of the Census.

1993. 1990 Census of Population and Housing, Population and Housing Unit Counts. http://www.census.gov/prod/cen1990/cph2/cph-2-1-1.pdf [accessed 30 May 2005].

U.S. Bureau of the Census.

1995. Arizona: Population of Counties by Decennial Census: 1900 to 1990. http://www.census.gov/population/cencounts/az190090.txt [accessed 30 May 2005].

U.S. Bureau of the Census.

2000. United States Census 2000. http://www.census.gov/main/www/cen2000.html [accessed 30 May 2005].

Vogt. C.

2003. Seasonal and permanent home owners' past experiences and approval of fuels reduction. In Homeowners, Communities, and Wildfire: Science Findings from the National Fire Plan, ed. P.L. Jakes, 63-73. USDA Forest Service Gen. Tech. Rep. NC-231.

Waddell, E.

Walker, P.

1977. The hazards of scientism: a review article. Human Ecology 5(1):69-76.

Wallrich, B.

2003. Reconsidering 'regional' political ecologies: toward a political ecology of the rural American West. Progress in Human Geography 27(1):7-24.

1996. The evolving role of community-based organizations in disaster recovery. Natural Hazards Observer 21(2):12-13.

Watts, M.J.

1983. On the poverty of theory: natural hazards research in context. In Interpretations of Calamity

Weaver, $\mathrm{H}$. from the Viewpoint of Human Ecology, ed. K. Hewitt, 231-262. Boston, MA: Allen and Unwin.

1951. Fire as an ecological factor in the southwestern ponderosa pine forests. Journal of Forestry White, A. 49:93-98.

1985. Presettlement regeneration patterns in a southwestern ponderosa pine stand. Ecology 66:589594.

Willems-Braun, B.

1997. Buried epistemologies: the politics of nature in (post)colonial British Columbia. Annals of the

Wisner, B. Association of American Geographers 87(1):3-32.

1993. Disaster vulnerability: scale, power, and daily life. GeoJournal 30(2):127-140. 
Wisner, B., P. Blaikie, T. Cannon, and I. Davis. 2004. At Risk: Natural Hazards, People's Vulnerability and Disasters, $2^{\text {nd }}$ Edition. London: Routledge.

Wisner, B., K. Westgate, and P. O'Keefe.

1976. Poverty and disaster. New Society 9(September):547-548.

WMCC (White Mountain Country Club).

2005. White Mountain Country Club homepage. http://www.wmccpinetop.com/ [accessed 20 June 2005].

Wolf, E.

1972. Ownership and political ecology. Anthropological Quarterly 45:201-205.

\begin{abstract}
The concept of marginalization, which is central to studies in political ecology, can be strengthened by incorporating a focus on the mutually constitutive concept of facilitation. Facilitation connotes how privileged groups are provided institutional forms of security in their pursuit of private gain, contributing to deleterious social and ecological outcomes. This paper builds on the concept of marginalization by outlining its application in previous studies. Next, it demonstrates how a dual focus on marginalization and facilitation can help strengthen understanding of the political ecology of risks, hazards and, disasters based on the case of urban wildfire hazards in Arizona's White Mountains. It concludes by discussing implications for understandings of differential risk and hazard vulnerability. In a world where privileged people are increasingly harnessing resources of state and market institutions to externalize risks and capitalize on environmental opportunities, facilitation offers a conceptual complement to marginalization and broadens the political ecology frame.
\end{abstract}

Keywords: hazard, vulnerability, risk, marginalization, fire, forest, landscape, Arizona

\title{
Résumé
}

L'idée de la marginalisation, qui est au coeur des études de l'écologie politique, peut être renforcée par l'incorporation d'une emphase sur l'idée de "facilitation" qui est sa contrepartie intrinsèque. "Facilitation" parle de la sécurité institutionnelle fournie aux groupes privilégiés pour leur poursuite de gain privé, ce qui contribue aux résultats écologiques et sociales délétères. D'abord, cet article contribue à notre comprensión de l'idée de marginalisation. Prochainement, il montre comment une emphase double sur la marginalisation et la facilitation peut nous assister dans la compréhension de l'écologie politique de risques naturels et de désastre à travers une étude des feux de brousse dans les Montagnes Blanches d'Arizona. Il finit par une discussion des implications pour la comprensión différentielle de la vulnérabilité de risque et de hasard. Dans un monde où les gens privilégiés ont une tendance accroissant d'utiliser les ressources de l'état et du marché pour externaliser les risques et maximaliser les bénéfices disponibles de l'environnement, "facilitation" offre un complément conceptuel au concept de marginalisation et élargit le cadre de l'écologie politique.

Mots-clés: risques naturels, vulnérabilité, marginalisation social, feu de forêt, paysage, Arizona

\section{Resumen}

El concepto de marginalización, central en los estudios de ecología política, puede ser consolidado a través de un enfoque en el concepto de facilitación, el cual es mutuamente constitutivo. La facilitación sugiere cómo grupos privilegiados son proporcionados con formas institucionales de seguridad en su búsqueda de beneficios individuales, trayendo resultados sociales y ecológicos deletéreos. Construyendo sobre el concepto de marginalización, este artículo traza su aplicación en estudios previos. Posteriormente, basado en un estudio de caso sobre el peligro de incendios silvestres con impacto en las zonas urbanas de las White Mountains de Arizona, el artículo demuestra como un enfoque simultáneo en marginalización y facilitación puede consolidar el entendimiento de la ecología política de riesgo, peligro y desastre. Finalmente, se concluye con una discusion sobre las implicaciones para el entendimiento de la vulnerabilidad diferenciada con respecto a riesgos y peligros. En un mundo donde la gente privilegiada está utilizando y controlando cada vez más los recursos de las instituciones del estado y del mercado, para exteriorizar riesgos y capitalizar en oportunidades ambientales, la facilitación ofrece un complemento conceptual a la marginalización y amplia el marco de la ecología política.

Palabras clave: peligro, vulnerabilidad, riesgo, marginalización, incendio, bosque, paisaje, Arizona 